\title{
INCIDENCE OF HYPERTENSION IN SCHOOLCHILDREN AND ADOLESCENTS: RELATIONSHIP WITH PHYSICAL ACTIVITY, CARDIORESPIRATORY FITNESS AND OBESITY
}

\author{
Anelise Gaya \\ Universidade Federal do Rio Grande do Sul, Porto Alegre, Rio Grande do Sul, Brasil \\ Luisa Aires \\ Universidade do Porto, Porto, Portugal \\ Júlio Mello \\ Universidade Federal do Rio Grande do Sul, Porto Alegre, Rio Grande do Sul, Brasil \\ Adroaldo Gaya \\ Universidade Federal do Rio Grande do Sul, Porto Alegre, Rio Grande do Sul, Brasil \\ Jorge Mota \\ Universidade do Porto, Porto, Portugal
}

\begin{abstract}
The present study examined the associations between changes over time in blood pressure (BP) with baseline and with varying levels of physical activity (PA), cardiorespiratory fitness (CRF) and body mass index (BMI). Longitudinal study, consisting of 221 young people aged between 8-17 years. The PA was assessed by questionnaire. Height was measured with a stadiometer and body mass with an electronic scale, both at school grounds. Maturacional stage was assessed through self evaluation conduced by pictures. CRF was estimated by maximal multistage $20 \mathrm{~m}$ shuttle-run test. BP was measured with an automatic sphygmomanometer. The major results suggest that overweight / obesity, male gender and the CRF dependent of BMI are risk factors for high blood pressure in school factors.
\end{abstract}

Key Words: high blood pressure; body mass index; cardiorespiratory fitness; youth

\section{Introduction}

Essential hypertension (EH) is a main risk factor for cardiovascular disease in adults (BERENSON et al., 1998). During the last decade, studies have appointed for an increasing number of children and adolescents with high levels of blood pressure (JAGO et al. 2006; MCNIECE et al. 2007). Around the world, approximately $22 \%$ of youth with overweight/obesity and $6.2 \%$ with normal weight have shown high levels of blood pressure (MENGHETTI et al. 2015; SOROF et al. 2004). These founds make EH as prevalent cardiovascular risk factors during childhood and adolescence with a moderate association with risk of development in adulthood as well as with an increase risk of cardiovascular events (BAO et al. 1995; GUERRA et al. 2003).

Consequently, identification of high levels of blood pressure and associated risk factors since infancy and adolescence may help for an early prevention of cardiovascular 
events later in life (JUHOLA et al. 2011; CHEN et al., 2008). As well as, of our knowledge there are just a few numbers of study aims to identify incidence of blood pressure among children and adolescents. This affirmation justified our research considering additional interesting in understanding hypertension behaviour and which factors are associated with this early prevalence of high levels of blood pressure among youth. In this context, several cross-sectional studies have shown the role of lifestyle associated with high levels of blood pressure in youth (ANDERSEN 1994; RIBEIRO et al. 2003; BARBA et al. 2006; MONYEKI, KEMPER 2008, CARSON, JANSEN 2011). Levels of physical activity (PA), cardiorespiratory fitness (CRF), sedentary behaviours, birth weight, family history and obesity have been appointed as main modifiable risk factors for early development of EH (LI et al. 2006; DIN-DZIETHAM et al. 2007, MONYEKI, KEMPER, 2008; SPAGNOLO et al. 2013).

Whilst among adults there are consistent results about the main contribution of obesity, PA and CRF on EH, on the other hand among children and adolescents there is a nonconvinces result: studies suggested a significant role of moderate to vigorous PA and CRF (GAYA et al. 2011; LEARY et al. 2008), however overweight and obese pandemic and birth weight seem to be a main risk factor for EH (FREEDMAN et al. 1999; BOREHAM et al. 2001; BUCHAN et al. 2014; SPAGNOLO et al. 2013). Jago et al. (2013) suggest that youth with healthy body mass index (BMI) showed small risk for developing EH when compared with risk of youth with healthy levels of CRF. However, seems to be important to highlight the several numbers of data that have shown a strong and independent association between CRF and hypertension in youth (ANDERSSEN et al. 2007; SILVA et al. 2012).

Thus, considering these results about the relationship between lifestyle and early development of high levels of blood pressure the aim of this study was to verify the relationship between incidence of EH with variation of PA, CRF and BMI in schoolchildren and adolescents, carry out the hypotheses that there are a high incidence of high levels of blood pressure in youth and BMI is a mean risk factors, however CRF seems to be a important mediator of this relationship.

\section{Methods}

\section{Participants and data collection}

This longitudinal study is a part of a research project aiming to analyze the prevalence of cardiovascular risk factors and the relationship with physical activity and cardiorespiratory fitness in a sample of children and adolescents from Porto-Portugal. This data was collected from one school of Porto-Portugal in 2006 and 2007 fall. Subjects were followed during two years. This sample comprised 221 subjects, 85 boys and 136 girls with ages between 8-17 years old, selected for convenience and had fully completed their data on blood pressure, physical activity index, body mass index and cardiorespiratory fitness during these two years. The exclusion criteria were the students don't want to participate in the study, the students have a disease that prevented the participation in the study and the parents don't have authorized to participate in the study. A written consent of the families was required. This study had permission to conduct by The Portuguese Ministry for Science and Technology, however in Portugal there isn't protocol number.

\section{Anthropometric and Body Composition Measurements}


Body height was measured to the nearest $\mathrm{mm}$ in bare or stocking feet with the adolescent standing upright against a Holtain Stadiometer. Weight was measured to the nearest $0.10 \mathrm{~kg}$, lightly dressed and after having breakfast served in school, using an electronic weight scale (Seca 708 portable digital beam scale). Body mass index was calculated from the ratio of body weight / body height $\left(\mathrm{m}^{2}\right)$ (MONYEKI, KEMPER, 2008). Children were categorized to overweight/obesity in agreement with cut off points suggested by Cole et al. (2000).

\section{Maturational Stage}

Regarding the maturational stage, data were collected by individual self-assessment conducted by pictures. Subject self assessed their stages of secondary sex characteristics. Each one was classified from pre-pubertal (stage I) until to mature stage (stage V). Stage of breast in females and pubic hair in males was evaluated according to the Tanner's criteria and previously used and validated in a similar sample (MOTA et al. 2002).

\section{Assessment of Physical Activity Index}

Physical Activity Index (PAI) was assessed by a questionnaire Application to a Portuguese population has previously been described elsewhere (MOTA, ESCULCAS 2002). The questionnaire had five questions with four answer choices (four-point scale): I) Do you take part in organized sport outside school? II) Do you take part in non-organized sport outside school? III) How many times per week do you take part in sport or physical activity for at least 20 minutes outside school? IV) How many hours per week do you usually take part in physical activity so much that you get out of breath or sweat outside school? V) Do you take part in competitive sport? The overall maximum number of points possible was 22 . The PAI was obtained according to the total sum of the points with increasing ranks from the sedentary to vigorous activity levels. Subjects with a score between 10 until 20 was considerate active (moderate-vigorous activity), while a score under of 10 was considerate inactive (sedentary activity).

\section{Cardiorespiratory Fitness}

CRF was estimated by maximal multistage $20 \mathrm{~m}$ shuttle-run test according to procedures described from FITNESSGRAM (MEREDITH, WELK 2003). The Progressive Aerobic Cardiovascular Endurance Run (PACER) test is a maximal aerobic fitness test. The test involves continuous running between the two lines in time to recorded beeps. The time between recorded beeps decrease each minute (level) requiring an increase in pace. The subjects continue until they are unable to keep pace with the beeps. There are a total of 21 levels, which would take approximately 21 minutes to complete. The score is the level and number of shuttles reached before the athlete was unable to keep up with the recording for two consecutive ends. The FITNESSGRAM was selected because of its ease of administration to large numbers of subjects and because the Shuttle Run Test predicted maximal aerobic capacity and showed significant correlation with $\mathrm{VO}_{2} \max (\mathrm{r}=0.80)$ suggesting that could be used as a measure of aerobic fitness in children (BOREHAM et al. 
1990). Children and adolescents were categorized as fit and unfit according to FITNESSGRAM cut points (MEREDITH, WELK 2003).

\section{Blood Pressure}

Blood pressure (BP) was measured with an automated oscilometric sphygmomanometer (DINAMAP model BP 8800) using a standard technique (DUARTE et al. 1999). Systolic blood pressure (SBP) and diastolic blood pressure (DBP) were measured in the right arm, with the subjects in the fasting state. The subjects were in the sitting position (without their legs crossed), with the right arm at heart level. Three standard pressure cuffs of correct size for children and adolescents $(9 \times 18 \mathrm{~cm}, 12 \times 23 \mathrm{~cm}, 14 \times 28 \mathrm{~cm})$ were used according to the published guidelines for BP assessment in children. The first and second measurements were taken after 5 and 10 min resting, being the mean of these measurements considered for statistical purposes. If these two measurements differed $2 \mathrm{~mm} \mathrm{Hg}$, the protocol was repeated (two new measurements that could not exceed $2 \mathrm{~mm} \mathrm{Hg}$ ). Children and adolescents were considerate with high values of BP according the guidelines of National High Blood Pressure (2004).

\section{Statistical Analysis}

All variable were checked for normality. Mean and standard deviations described participant's characteristics. The changes at the mean on variables: PAI, CRF and BP between time T0 and T1 were verified through repeated measurement analysis of variance (General Linear Model) stratified by normal and high blood pressure values. Pairwise Comparisons were made for each variable and Bonferroni correction used to verify where the differences were. Differences between the two assessments were verified thought compared between frequencies of HBP in Time 0 and Time 1. Differences between time 0 and time 1 ( $\Delta=\mathrm{T} 1-\mathrm{T} 0)$ was calculated for BMI, PAI, CRF, SBP and DBP. Logistic Binary regressions were used to examine association between baseline variables and changes $(\Delta)$ in BMI, CRF and PA with high blood pressure values over one year. These regressions models were adjusted by sexual maturation, age, gender and height. All statistical analyzes were performed with the Statistical Software Package SPSS 20.0 from IBM, and level of significance was set up 0.05.

\section{Results}

Table 1 - Description sample characteristics and differences between T0 and T1 stratified by normal and high systolic blood pressure values

\begin{tabular}{|c|c|c|c|c|c|}
\hline & $\begin{array}{l}\text { T0 } \\
\text { Mean } \pm \text { SD }\end{array}$ & 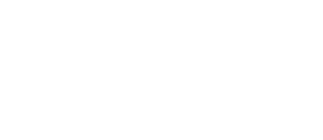 & D & $\begin{array}{l}\text { T1 } \\
\text { Mean } \pm S\end{array}$ & \\
\hline & Normal & HBP & & Normal & HBP \\
\hline (years) ${ }^{\text {Age }}$ & $14.53 \pm 1.3$ & $15.02 \pm 1.21$ & $37 *$ & $15.71 \pm 1$ & $16.00 \pm 1$ \\
\hline
\end{tabular}


Weight

48

(m)

Height

BMI

$\left(\mathrm{kg} / \mathrm{m}^{2}\right)$

CRF

(laps)

55

$39.14 \pm 19$.

$9+$

$\Delta=5.56$

$11.30 \pm 4.1$

PAI 4

(index)

(mmHg)

SBP

33

DBP

(mmHg)

$\Delta=0.59$

$123.38 \pm 9$.

$$
\Delta=-3.47
$$

$63.85 \pm 11$.

36
$56.50 \pm 10$.

$67.72 \pm 12.4$

$\Delta=2.68$

$1.63 \pm 0.08$

$\Delta=0.02$

$21.06 \pm 3.1$

$23.44 \pm 4.51$

$38 *$

$\Delta=0.23$

$1.70 \pm 0.08+8^{*}$

$\Delta=0.07$
$1.65 \pm 0.0$

$1.72 \pm 0.0$

$21.87 \pm 3$

$23.67 \pm 5$

$19+$

$62.08 \pm 27$

$1.72 *$

$.97 * *+$

$11.89 \pm 4$

$13.00 \pm 4$.

$12.23 \pm 4.20 \quad 28 *$

$\Delta=0.77$

$146.91 \pm 6.6$

$119.91 \pm$

$10.55^{*}$

$.61 * *+$

$141.33 \pm 9$

$\Delta=-5.58$

$71.93 \pm 5.04$

$\Delta=0.19$

$\Delta=1.12$

$64.04 \pm 8$.

$73.05 \pm 6$

83

$50+$

Repeated Measured between T0 and T1; *Significant differences between normotensive group between T0 and T1 $(\mathrm{p}<0.05)$; ** Significant differences between high blood pressure (HBP) group between T0 and T1 $(\mathrm{p}<0.05) ;+$ Significant differences between normotensive and high blood pressure group ( $\mathrm{p}<0.05) ; \Delta(\mathrm{t} 1-\mathrm{t} 0)$ Mean differences between T1 and T0 for both normal and HBP groups; HBP: high blood pressure values (percentil 75 adjusted by sex and age); CRF: cardiorespiaratory fitness; PAI: physical activity index; SBP: systolic blood pressure; DBP: diastolic blood pressure; m: meters; kg/m²: kilograms divided by square meter; laps: laps completed in test; $\mathrm{mmHg}$ : millimeters of mercury; SD: standard deviation.

Table 1 shows characteristics of the sample stratified by normal and high BP values in T0 and T1. Nearly all variables showed an increase in mean values in time 1 . The highest mean values of all variables are observed in HBP groups. SBP was the only variable that showed a significant decrease between T0 and T1. Mean values of BMI did not show a significant increase in HBP groups. However, the highest mean value was verified in HBP groups.

Table 2: Frequency and percentage of children and adolescents changed from normal to HBP group over one year

\begin{tabular}{clll}
\hline \hline HBP & - & Frequency & Percentage \\
$\begin{array}{c}\text { Normal } \\
\text { Normal }\end{array}$ & 10 & $4.3 \%$ \\
\hline
\end{tabular}




\begin{tabular}{|c|c|c|c|}
\hline & HBP & 46 & $19.8 \%$ \\
\hline HBP & Normal & 15 & $6.5 \%$ \\
\hline
\end{tabular}

HBP: high blood pressure values; \%: percentual values

Table 2 shows the frequency and percentage of children and adolescents that changed from one to another group. The percentage of children that changed from normal to HBP group $(6.5 \%)$ was higher than children and adolescents that left the normal group (4.3\%).

Table 3: Adjusted odds ratio for high systolic blood pressure group by body mass index, cardiorespiratory fitness and physical activity index in one year

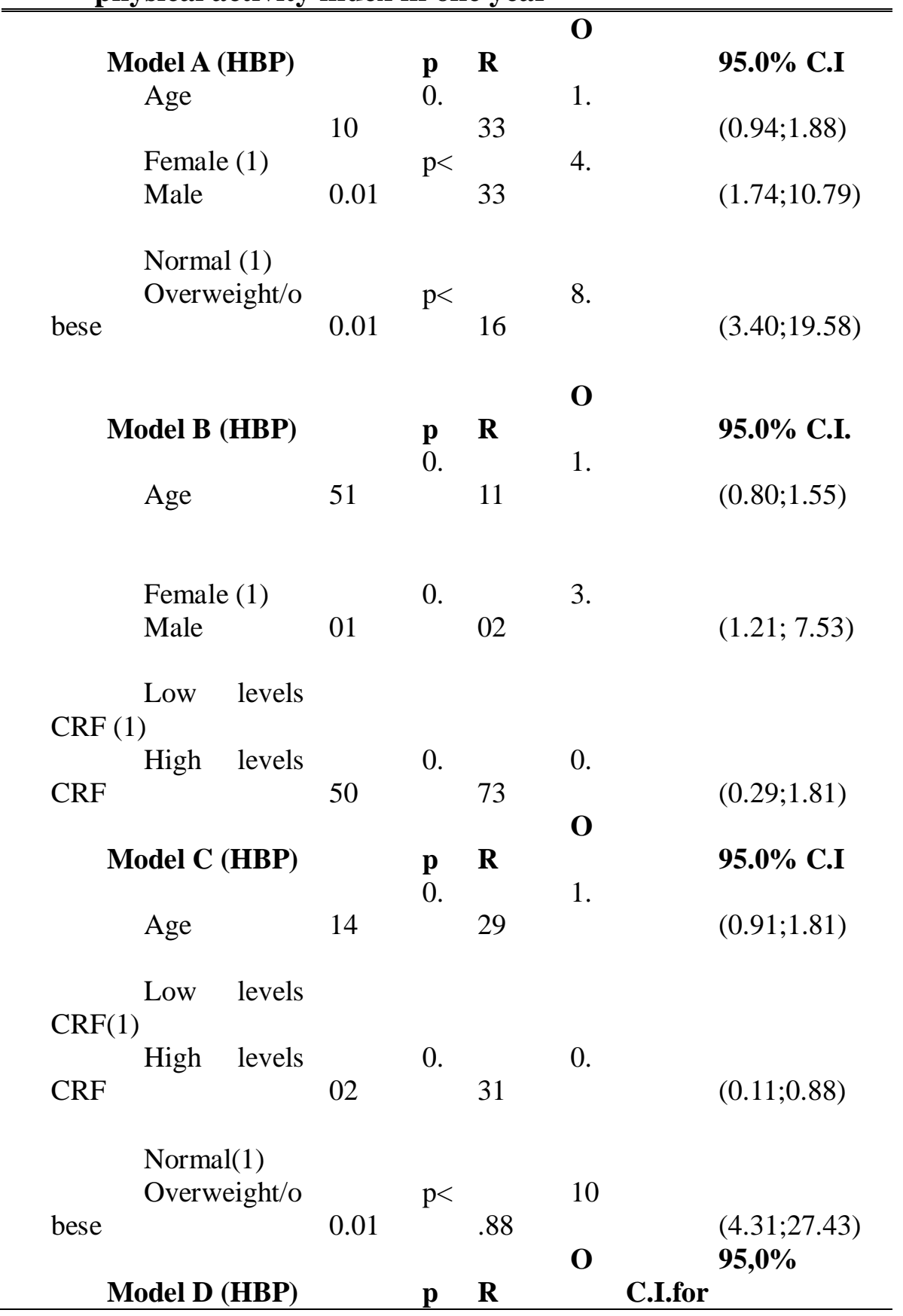




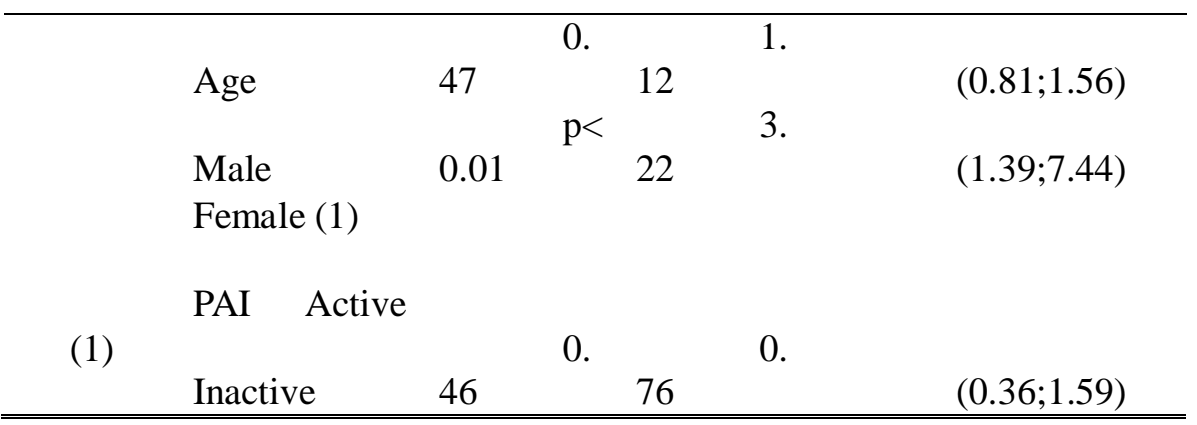

(1): reference group for statistical analyses; CRF: cardiorespiratory fitness; HBP: high blood pressure; PAI: physical activity index; All model are adjusted by sexual maturation and height; p: significance value; OR: odds ratio; CI: confidence interval.

Table 3 shows the outcomes associated with risk of moving from normal BP to HBP group and the risk of staying in HBP group for one year. Baseline variables showed significant association with risk of being in HBP groups (Table 3). Children and adolescents classified as male and overweight/obese in baseline were significantly more likely to be categorized with HBP values than female and normal weight children and adolescents. Furthermore, high baseline levels of CRF were inversely associated with risk to having HBP values. However, the relationship between HBP and CRF was significant only when BMI was included in the model. PAI did not show significant results.

Table 4: Adjusted odds ratio for high systolic blood pressure group by mean differences $(\Delta)$ of body mass index, cardiorespiratory fitness and physical activity between time 1 and time 0

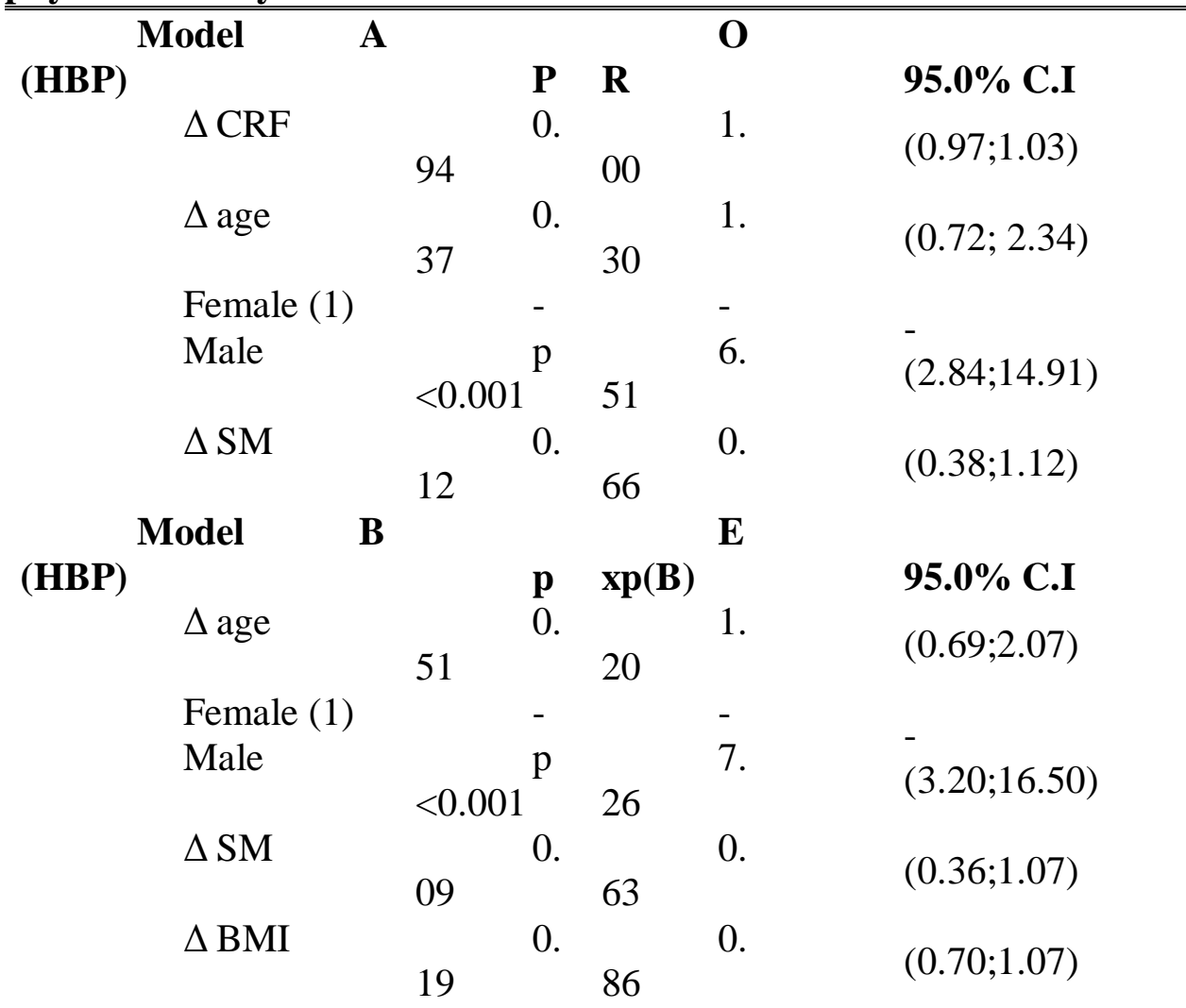




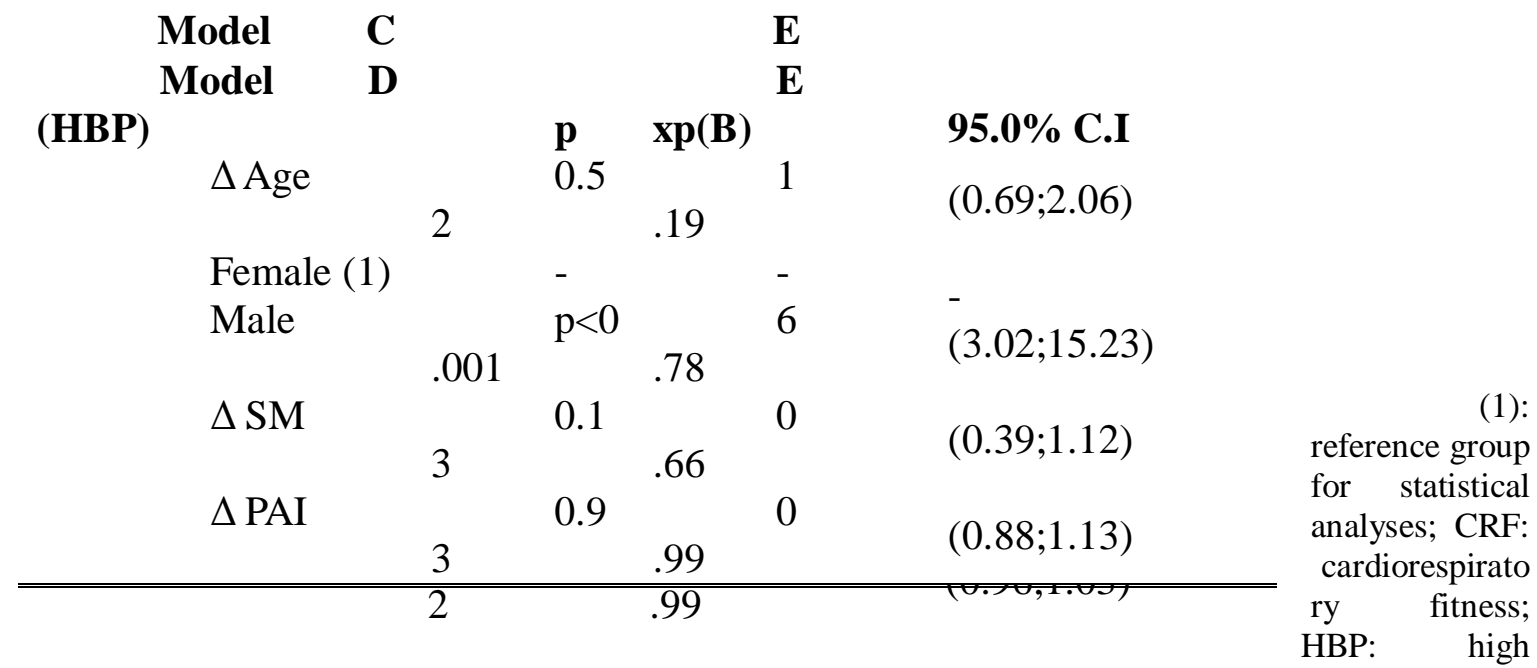

blood pressure; PAI: physical activity index; All model are adjusted by height; p: significance value; OR: odds ratio; $\mathrm{CI}$ : confidence interval.

Table 4 shows association between the risk of being in HBP group with variation of BMI, PAI and CRF $(\Delta=\mathrm{T} 1-\mathrm{T} 0)$ for one year. Our results did not show significant association between HBP with variation of BMI, CRF and PAI.

\section{Discussion}

The purpose of this study was to investigate the relationship between incidence of HT with variation of physical activity, CRF and BMI in HT. The main predictors were overweight/obesity in baseline, male gender and the low levels of CRF that was associated with HT dependent of overweight/obesity. It is important to highlight that all of these associations were independently of the role of growth, maturation and development variables and are in agreement with recent papers that have suggested obesity measured by BMI as a strong and independent outcome associated with early development of HT (JAGO et al. 2006; DIN-DZIETHAM et al. 2007; OSTCHEGA et al. 2009).

Despite of BMI as a main risk factor associated with early development of HT, our results did not suggest a directly relationship between CRF and incidence of HT. Whilst current prospective cohort study with 1016 youths from Oslo published by Kvaavik et al. (2009) shown an inverse relationship between CRF and systolic and diastolic values in baseline time and in a second time two years later and Andersen (1996) in a traditional research shows a highly significant relationship between VO2 max and BP as well as Maxinova et al. (2009) suggests a relationship between declines of 1 moderate vigorous physical activity session per week, each year, for $0.29 \mathrm{~mm} \mathrm{Hg}$ and $0.19 \mathrm{~mm} \mathrm{Hg}$ high systolic blood pressure boys and girls, respectively, in early adolescence and $0.40 \mathrm{~mm} \mathrm{Hg}$ and 0.18 $\mathrm{mm} \mathrm{Hg}$ respectively in late adolescence (MAXIMOVA et al. 2009), our data is in disagreement of these several studies since the association between HT and CRF was verified just when BMI was included on the regression model.

If there are non-convincing results among the relationship between CRF and HT in children and adolescents, the main conclusion about the role of CRF on cardiovascular risk factors often comes from studies with adults, where CRF have been indicated as a strong predictor for cardiovascular risk factors and also associated with mortality rate, independently of body fatness. However, there are several cross sectional studies in agreement with our data 
(BOREHAM et al. 2001; EKELUND et al. 2007; BUCHAN et al. 2014) that appointed for a relationship between CRF and cardiovascular risk factors among children and adolescents population dependent of BMI (BOREHAM et al. 2001; EKELUND et al. 2007; DENCKER et al. 2008). In our opinion this disagreement among results of youth and adults may is explained if we considering that often children and adolescents do not have cardiovascular risk factors and also cardiovascular disease established. They could be in the beginning of the atherosclerotic process, and obesity seems to be the main risk factor (FREEDMAN et al. 2009).

These results place BMI as an important predictor associated with HT Overweight/obese children and adolescents showed a higher risk than normal weight to developing HT. These results is in agreement with a recent review proposed by Spagnolo et al. (2013) where among other risk factors such as birth weight, family history of hypertension, reduction of BMI are associated with modification on levels of BP.

However, the mechanism by which obesity is associated with risk for early development of cardiovascular risk factors as well as associated with the risk for early development of clustering of cardiovascular risk factors is not yet fully understood. Several studies appointed obesity as main risk factors associated with insulin resistance, which in turn has a significant role on the development of other cardiovascular risk factor (EKELUND et al. 2007). Moreover, about this physiologic affirmation it is important underline the inflammatory consequences in response of obesity associated with cardiometabolic consequences.

Interestingly, physical activity did not show significant association with HT. If in other studies moderate physical activity as well as sedentary physical activity measured by accelerometer showed a significant association with children BP, in this study we did not find association (REILLY et al. 2008, GAYA et al. 2011). Probably, it is because questionnaire is a not adequate method to measure physical activity among youth. Beyond the measurement of physical activity by accelerometers, studies that appointed for a relationship between physical activity and HT usually considerate the intensity of physical activity.

Our longitudinal data appointed for a tendency to an emergent number of children and adolescents with HT. These results seem to be an important public health data. In one year the number of children and adolescents with HT was higher than which one with low $\mathrm{BP}$ values considerate. In a descriptive way, this data appears to appoint for the necessity of more studies included children and adolescents data aimed to understand the occurrence and incidence of HT. Nevertheless, our study showed several limitations such as the size of our sample, the short time between the two assessments of BP, as well as the indirect methods that we used to measure BMI, CRF and physical activity.

On the other hand, the strength of our research was that this is a longitudinal study, which aimed to verify the association between the changes over the time of BP and the relationship with baseline and variation of physical activity, CRF and BMI in a sample of children and adolescents. This research comprised two measurements of the same children and adolescents. Our results suggest the necessity of strategies to prevent HT among students throughout the control of obesity pandemic. High levels of CRF, a dose-response of regular exercise was associated with this relationship between BMI and BP. These results appointed for the necessity of more researches aimed to identify the role of CRF on cardiometabolic risk factors, especially HT among schoolchildren and adolescents. 


\title{
Conclusion
}

Our data appointed for a crescent number of children and adolescents which early developing HT. In a period of one year the incidence of HT was approximately $6.5 \%$. The main predictors of this incidence were overweight/obesity. The protection role of CRF seems to be directly associated with overweight/obesity not with HT. However considerate children and adolescents with overweight/obesity, low levels of CRF was an added risk.

\section{INCIDÊNCIA DE HIPERTENSÃO EM CRIANÇAS E ADOLESCENTES ESCOLARES: RELAÇÃO COM A ATIVIDADE FÍSICA, APTIDÃO CARDIORRESPIRATÓRIA E OBESIDADE}

\begin{abstract}
Resumo
O presente estudo verificou as associações entre as alterações ao longo do tempo dos níveis de pressão arterial (PA) com os valores basais e com a variação dos níveis de atividade física (AF), aptidão cardiorrespiratória (ApC) e índice de massa corporal (IMC). Estudo longitudinal, composto por 221 jovens com idades entre 8-17 anos. A AF foi avaliada através de questionário. A estatura foi verificada com um estadiometro e a massa corporal com uma balança eletrônica, ambos nas dependências da escola. A maturação sexual foi verificada através de auto avaliação com auxílio de imagens. A ApC foi avaliada através do teste Shuttle run-20m. A PA foi aferida com um esfigmomanômetro automático. Os principais resultados sugerem que o sobrepeso/obesidade, sexo masculino e a ApC dependente do IMC são fatores de risco de pressão arterial elevada em escolares.

Palavras-chave: hipertensão arterial; índice de massa corporal; escolares; aptidão cardiorrespiratória

\section{INCIDENCIA DE LA HIPERTENSIÓN EN NIÑOS Y ADOLESCENTES ESTUDIANTES: RELACIÓN CON LA ACTIVIDAD FÍSICA, CAPACIDAD CARDIORRESPIRATORIA Y OBESIDAD.}

\section{Resumem}

Este estudio examinó las asociaciones entre los cambios en los niveles de presión arterial de tiempo (PA) con la línea de base y el cambio en los niveles de actividad física (AF), la aptitud cardiorrespiratoria (AFT) y el índice de masa corporal (IMC ). Estudio longitudinal, compuesta por 221 jóvenes de entre 8 a 17 años. La AF se evaluó mediante un cuestionario. Altura se midió con un estadiómetro y la masa corporal con una balanza electrónica, tanto en la escuela. La madurez sexual se evaluó a través de la autoevaluación con imágenes de ayuda. El AFT se evaluó mediante el traslado de pruebas previo 20m. PA se midió con un esfigmomanómetro automatizado. Los principales resultados sugieren que el sobrepeso / obesidad, masculina y dependiente AFT en el IMC son factores de riesgo de hipertensión arterial entre los escolares.

Palabras-chave: Hipertensión; índice de masa corporal; escuela; aptitud cardiorrespiratoria 


\section{References}

ANDERSEN, Lars Bo. Blood pressure, physical fitness and physical activity in 17-year-old Danish adolescents. Journal of internal medicine, v. 236, n. 3, p. 323-330, 1994

ANDERSEN, Lars Bo. Tracking of risk factors for coronary heart disease from adolescence to young adulthood with special emphasis on physical activity and fitness. A longitudinal study. Danish medical bulletin, v. 43, n. 5, p. 407-418, 1996.

ANDERSSEN, Sigmund A. et al. Low cardiorespiratory fitness is a strong predictor for clustering of cardiovascular disease risk factors in children independent of country, age and sex. European Journal of Cardiovascular Prevention \& Rehabilitation, v. 14, n. 4, p. 526$531,2007$.

BAO, Weihang et al. Essential hypertension predicted by tracking of elevated blood pressure from childhood to adulthood: the Bogalusa Heart Study. American Journal of Hypertension, v. 8, n. 7, p. 657-665, 1995.

BARBA, Gianvincenzo et al. Body mass, fat distribution and blood pressure in Southern Italian children: results of the ARCA project. Nutrition, metabolism and cardiovascular diseases, v. 16, n. 4, p. 239-248, 2006.

BERENSON, Gerald S. et al. Association between multiple cardiovascular risk factors and atherosclerosis in children and young adults. New England journal of medicine, v. 338, n. 23, p. 1650-1656, 1998.

BOREHAM, C. A.; PALICZKA, V. J.; NICHOLS, A. K. A comparison of the PWC170 and 20-MST tests of aerobic fitness in adolescent schoolchildren. The Journal of sports medicine and physical fitness, v. 30, n. 1, p. 19-23, 1990.

BOREHAM, COLIN et al. Fitness, fatness, and coronary heart disease risk in adolescents: the Northern Ireland Young Hearts Project. Medicine and science in sports and exercise, v. 33, n. 2, p. 270-274, 2001.

BUCHAN, D. S. et al. Independent associations between cardiorespiratory fitness, waist circumference, BMI, and clustered cardiometabolic risk in adolescents. American Journal of Human Biology, v. 26, n. 1, p. 29-35, 2014.

CARSON, Valerie; JANSSEN, Ian. Volume, patterns, and types of sedentary behavior and cardio-metabolic health in children and adolescents: a cross-sectional study. BMC Public Health, v. 11, n. 1, p. 274, 2011.

CHEN, Xiaoli; WANG, Youfa. Tracking of blood pressure from childhood to adulthood a systematic review and meta-regression analysis. Circulation, v. 117, n. 25, p. 3171-3180, 2008. 
COLE, Tim J. et al. Establishing a standard definition for child overweight and obesity worldwide: international survey. Bmj, v. 320, n. 7244, p. 1240, 2000.

DENCKER, Magnus et al. Daily physical activity related to aerobic fitness and body fat in an urban sample of children. Scandinavian Journal of Medicine \& Science in Sports, v. 18, n. 6, p. 728-735, 2008.

DIN-DZIETHAM, Rebecca et al. High blood pressure trends in children and adolescents in national surveys, 1963 to 2002. Circulation, v. 116, n. 13, p. 1488-1496, 2007.

DUARTE, J. A. et al. Blood pressure in pediatric years (8-13 years old) in the Oporto region. Revista portuguesa de cardiologia: orgao oficial da Sociedade Portuguesa de Cardiologia $=$ Portuguese journal of cardiology: an official journal of the Portuguese Society of Cardiology, v. 19, n. 7-8, p. 809-820, 1999.

EKELUND, Ulf et al. Independent associations of physical activity and cardiorespiratory fitness with metabolic risk factors in children: the European youth heart study. Diabetologia, v. 50, n. 9, p. 1832-1840, 2007.

FREEDMAN, David S. et al. Relation of body mass index and skinfold thicknesses to cardiovascular disease risk factors in children: the Bogalusa Heart Study. The American journal of clinical nutrition, v. 90, n. 1, p. 210-216, 2009.

FREEDMAN, David S. et al. The relation of overweight to cardiovascular risk factors among children and adolescents: the Bogalusa Heart Study.Pediatrics, v. 103, n. 6, p. 1175-1182, 1999.

GAYA, A. R. et al. Association of leisure time physical activity and sports competition activities with high blood pressure levels: study carried out in a sample of Portuguese children and adolescents. Child: care, health and development, v. 37, n. 3, p. 329-334, 2011.

GUERRA, Sandra et al. Estabilidade de factores de risco das doenças cardiovasculares numa amostra de crianças e adolescentes portugueses da área do grande Porto. Rev Port Cardiol, v. 22, n. 2, p. 167-182, 2003.

JAGO, R. et al. Prevalence of abnormal lipid and blood pressure values among an ethnically diverse population of eighth-grade adolescents and screening implications. Pediatrics, v. 117, n. 6, p. 2065-2073, 2006.

JAGO, R.1 et al. BMI change, fitness change and cardiometabolic risk factors among 8th grade youth. Pediatric exercise science, v. 25, n. 1, p. 52, 2013.

JUHOLA, J. et al. Tracking of serum lipid levels, blood pressure, and body mass index from childhood to adulthood: the cardiovascular risk in young Finns Study. The Journal of Pediatrics, v.159, n.4, p.584-90, 2011. 
KVAAVIK, E., K. I. K, et al. Physical fitness and physical activity at age 13 years as predictors of cardiovascular disease risk factors at ages 15, 25, 33, and 40 years: extended follow-up of the Oslo Youth Study. Pediatrics, v. 123 n. 1,p. 80-86, 2009.

LEARY, Sam D. et al. Physical Activity and Blood Pressure in Childhood Findings From a Population-Based Study. Hypertension, v. 51, n. 1, p. 92-98, 2008.

LI, C. et al. Birth weight, puberty, and systolic blood pressure in children and adolescents: a longitudinal analysis. Journal of human hypertension, v. 20, n. 6, p. 444-450, 2006.

MAXIMOVA, Katerina et al. Declines in physical activity and higher systolic blood pressure in adolescence. American journal of epidemiology, p. 255, 2009.

MCNIECE, Karen L. et al. Prevalence of hypertension and pre-hypertension among adolescents. The Journal of pediatrics, v. 150, n. 6, p. 640-644. e1, 2007.

MENGHETTI, E. et al. Hypertension and obesity in Italian school children: The role of diet, lifestyle and family history. Nutrition, Metabolism and Cardiovascular Diseases, v. 25, n. 6, p. 602-607, 2015.

MEREDITH, Marilu D.; WELK, Greg. Fitnessgram: Test administration manual. Human Kinetics Publishers, 2003.

MONYEKI, K. D.; KEMPER, H. C. G. The risk factors for elevated blood pressure and how to address cardiovascular risk factors: a review in paediatric populations. Journal of human hypertension, v. 22, n. 7, p. 450-459, 2008.

MOTA, Jorge et al. Association of maturation, sex, and body fat in cardiorespiratory fitness. American Journal of Human Biology, v. 14, n. 6, p. 707-712, 2002.

MOTA, Jorge; ESCULCAS, Carlos. Leisure-time physical activity behavior: structured and unstructured choices according to sex, age, and level of physical activity. International Journal of Behavioral Medicine, v. 9, n. 2, p. 111-121, 2002.

OSTCHEGA, Yechiam et al. Trends of elevated blood pressure among children and adolescents: data from the National Health and Nutrition Examination Survey 19882006. American journal of hypertension, v. 22, n. 1, p. 59-67, 2009.

REILLY, John J. et al. Objective measurement of physical activity and sedentary behaviour: review with new data. Archives of disease in childhood, v. 93, n. 7, p. 614-619, 2008.

RIBEIRO, José et al. Overweight and obesity in children and adolescents: relationship with blood pressure, and physical activity. Annals of human biology, v. 30, n. 2, p. 203-213, 2003.

SILVA, G. et al. Cardiorespiratory Fitness Associates with Metabolic Risk Independent of Central Adiposity. Int J Sports Med, v. 34, p. 912-916, 2012. 
SOROF, Jonathan M. et al. Overweight, ethnicity, and the prevalence of hypertension in school-aged children. Pediatrics, v. 113, n. 3, p. 475-482, 2004.

SPAGNOLO, Amedeo et al. Focus on prevention, diagnosis and treatment of hypertension in children and adolescents. Ital J Pediatr, v. 39, p. 20, 2013.

The fourth report on the diagnosis, evaluation, and treatment of high blood pressure in children and adolescents. US Department of Health and Human Services, National Institutes of Health, National Heart, Lung, and Blood Institute, National Hight Blood Pressure Education Program, 2005.

Recebido em: 11/12/2014

Revisado em: 21/07/2015

Aprovado em: 18/08/2015

Endereço para correspondência:

Anelise Gaya

anegaya@gmail.com

Av. Paulo Gama, 110 - Bairro Farroupilha

Porto Alegre - Rio Grande do Sul

CEP: 90040-060 